\title{
PARTISIPASI WARGANET DALAM MENGIDENTIFIKASI KOMUNIKASI INTELEKTUAL NARASUMBER POLITIK TERKAIT PERKEMBANGAN HASIL PEMILU 2019
}

\author{
Dinar Soelistyowati \\ Fakultas Ilmu Komunikasi Universitas Bhayangkara Jakarta Raya, Bekasi. \\ dinar.soelistyowati@dsn.ubharajaya.ac.id \\ Diajukan: 06-09-2019; Direview: 18-09-2019; Diterima: 22-12-2019;
}

\begin{abstract}
This study aims to identify and analyze the forms of intellectual communication expressed by political sources related to the development of the 2019 Election results. The discussion in this study includes an overview of the euphoria of the 2019 Election which continues to the position of political communication as part of political interviewees' intellectuality, the appearance of social media and social network as new mediator of millenial citizen, as well as the citizen's impact as the observer of the political interviewees in discussing the result of 2019 Election's development. This discussion uses a qualitative approach that uses a combination of semiotics theory with symbolic interactionism, which those are part of constructivism paradigm. The results of this study indicate that intellectual communication patterns formed by political speakers related to the development of the 2019 Election results are able to function as a trigger for citizens to participate by becoming part of a society that is digitally informed about following and waiting for the results of the 2019 Election development for the creation of a better Indonesian nation.
\end{abstract}

Keywords: Intellectual Communication, Political Speaker, Netizen, The Development of 2019 Election Result.

\begin{abstract}
Abstrak
Penelitian ini bertujuan untuk mengidentifikasi dan menganalisis bentuk komunikasi intelektual yang dinyatakan oleh narasumber politik terkait dengan perkembangan hasil Pemilu 2019. Pembahasan dalam penelitian ini meliputi gambaran umum mengenai euforia Pemilu 2019 yang berlanjut pada posisi komunikasi politik sebagai bagian dari intelektualitas narasumber politik, kemunculan media sosial dan jejaring sosial sebagai mediator baru warganet millenial, serta pengaruh warganet sebagai pengamat narasumber politik dalam membahas hasil perkembangan pemilu 2019. Pembahasan ini menggunakan pendekatan kualitatif yang menggunakan perpaduan antara teori semiotika dengan teori interaksionisme simbolik yang merupakan bagian dari paradigma konstruktivisme. Hasil dari penelitian ini menunjukkan bahwa pola komunikasi intelektual yang dibentuk oleh para narasumber politik terkait dengan perkembangan hasil Pemilu 2019 mampu berfungsi sebagai pemicu warganet untuk ikut berpartisipasi dengan menjadi bagian dari masyarakat yang melek informasi secara digital, juga mampu mengikuti dan menanti hasil dari perkembangan Pemilu 2019 demi terciptanya bangsa Indonesia yang lebih baik.
\end{abstract}

Kata kunci: Komunikasi Intelektual, Narasumber Politik, Warganet, Perkembangan Hasil Pemilu 2019

\section{PENDAHULUAN}

$\mathrm{D}$ i era dinamika seperti saat ini, komunikasi semakin tidak bisa dipisahkan dari kehidupan manusia. Teknologi komunikasi juga meningkatkan kapabilitasnya pada aspek efisiensi dan fleksibilitas terhadap pemenuhan manusia dalam mengakses dan mencari informasi sesuai dengan apa yang dibutuhkan. Hasil dari kondisi ini mengakibatkan terciptanya suatu lingkungan baru di mana manusia berevolusi menjadi homo notitia conquisitor (manusia pencari informasi). 
Informasi menjadi semakin bervariasi, baik dari segi konten maupun tautan dalam mengaksesnya. Hal ini mengakibatkan banyak orang berbondongbondong mencari tautan informasi yang dibutuhkan tanpa henti. Salah satu bidang informasi yang banyak di cari oleh masyarakat adalah politik, Konten politik belakangan ini mendapatkan banyak sorotan dan tanggapan dari masyarakat terutama pada perkembangan hasil Pemilu 2019. Kita bisa melihat di beberapa stasiun televisi mengenai bagaimana hasil dari pemungutan suara ini berkembang. Selama perkembangan tersebut masih berjalan, kita juga disuguhkan untuk melihat berita yang menyiarkan pertandingan antara kedua kubu dari masing-masing pasangan calon yang saling tuding dan saling klaim kebenaran serta pembenaran dengan beradu data yang dianggap akurat menurut versi masing-masing. Banyak juga tayangan berita mengenai narasumber politik di beberapa acara berita televisi yang saling beradu pandangan dan argumen serta berspekulasi mengenai bagaimana hasil dari perkembangan penghitungan suara Pemilu 2019.

Belakangan ini hadirnya sosial media sebagai alat penyebaran informasi yang ditujukan kepada masyarakatataupun pemilih dalam pemilu dianggap sebagai langkah yang efektif dan penting, terlebih khusus dalam membentuk opini dan pengaturan agenda politik (Woolley, Limperos, \& Oliver, 2010). Adapun media sosial yang dimaksud dalam artikel ini adalah menyangkut Facebook, Twitter, Instagram dan termasuk platform Whatsapp dengan kriteria rentang usia 19-34 dengan jarak pendidikan SMA hingga Tingkat Pascasarjana sebagai kontributor utama pengguna internet di Indonesia menurut survei Asosiasi Penyelenggara Jasa Internet Indonesia (APJII) (APJII, 2018: 6).

Melihat situasi ini tentunya seperti melihat tayangan drama yang tidak jelas ujung ceritanya. Sebagai imp lementasi nyata dari latar belakang situasi tersebut, publik yang saat ini telah berasimilasi dengan teknologi, menjadi melek informasi dengan menjadi netizen (warganet) untuk memuaskan keingintahuannya dengan mengakses sejumlah tautan informasi yang mungkin relevan. Namun, menjadi warganet tidak selalu menjadikan mereka sebagai pihak yang paling melek terhadap informasi terkini. Hal ini dikarenakan kurangnya pengetahuan dan wawasan yang diperlukan untuk mengidentifikasi setiap bentuk transaksi komunikasi di antara narasumber politik dalam membahas temuan fakta mengenai sejumlah kecurangan yang terjadi pada proses penghitungan suara Pilpres 2019. Masalah ini juga diperparah dengan minimnya kewaspadaan mereka dalam mengakses berita yang dibutuhkan. Seringkali pencarian berita mereka berakhir pada berita hoaks yang justru memprovokasi mereka kepada tindakan amoral seperti ujaran kebencian dan lain sebagainya. Ini mengakibatkan ketidakpahaman dan menciptakan pemikiran yang ambigu serta kesalahan pembuatan kesimpulan bagi mereka sendiri dalam memproses makna sebenarnya yang dinyatakan oleh para narasumber politik.

Mengacu pada latar belakang tersebut, tujuan dari peneliti melakukan penelitan ini adalah memberikan pengetahuan dasar tentang bagaimana mengidentifikasi dan menganalisis setiap bentuk komunikasi yang dinyatakan oleh masing-masing individu, khususnya yang dinyatakan oleh para narasumber politik terkait dengan temuan-temuan fakta seputar perkembangan hasil Pemilu 2019, dan sebagai tolok ukur masyarakat dalam mengamati, menganalisis, dan membahas secara kolektif (sesama warganet) terhadap tindak komunikasi yang dilakukan oleh narasumber politik dalam pembahasan berita politik khususnya mengenai perkembangan hasil Pemilu 2019 melalui media sosial dan jejaring sosial.

Untuk memahami hal tersebut, maka menjadi penting untuk dilakukan pengkajian terkait dengan partisipasi warganet dalam melakukan analisisnya terhadap setiap bentuk komunikasi yang dikemukakan oleh narasumber politik ketika membahas mengenai perkembangan hasil Pemilu 2019. Melalui penelitian ini, diharapkan hasilnya dapat dijadikan sebagai referensi dan tolok ukur pemerintahan Indonesia dalam mengkaji, mempertimbangkan, dan merevisi peraturanperaturan yang dapat menunjang hasil yang lebih baik pada Pemilu periode 2024 mendatang serta sebagai dapat memberikan cerminan dan gambaran 
tentang implementasi Pemilu yang didasarkan pada pemikiran masyarakat Indonesia yang kritis, independen, dan demokratis.

Penelitian terdahulu yang relevan dan dapat dijadikan sebagai acuan peneliti dalam melakukan penelitian ini adalah penelitian yang dilakukan oleh Ida Wiendijarti yang berjudul "Pengaruh Kredibilitas Narasumber Berita Politik rerhadap Internalisasi Nilai Berita Politik Pada Masyarakat". Tujuan dari penelitiannya adalah untuk mengidentifikasi apakah ada pengaruh yang signifikan antara kredibilitas narasumber politik dengan internalisasi nilai berita politik pada masyarakat. Hasil dari penelitiannya menunjukkan bahwa terdapat korelasi yang positif dan signifikan antara kredibilitas narasumber politik dengan internalisasi nilai berita politik pada masyarakat. Intelektual merupakan faktor tertinggi yang dapat mempengaruhi narasumber berita politik, diikuti dengan pihak birokrat dan pejabat politik elit (Wiendijarti, 2008).

Sedangkan penelitian yang dilakukan oleh penelitisaatini(2019)berjudul"PartisipasiWarganet dalam Mengidentifikasi Komunikasi Intelektual Narasumber Politik Terkait Perkembangan Hasil Pemilu 2019". Penelitannya bertujuan untuk memberikan pengetahuan dasar tentang bagaimana mengidentifikasi dan menganalisis setiap bentuk komunikasi yang dinyatakan oleh masing-masing individu, khususnya yang dinyatakan oleh para narasumber politik terkait dengan temuantemuan fakta seputar perkembangan hasil Pemilu 2019, serta sebagai tolok ukur masyarakat dalam mengamati, menganalisis, dan membahas secara kolektif (sesama warganet) terhadap tindak komunikasi yang dilakukan oleh narasumber politik dalam pembahasan berita politik khususnya mengenai perkembangan hasil Pemilu 2019 melalui media sosial dan jejaring sosial. Penelitian ini pun dilakukan secara kualitatif eksploratif dengan teknik partisipasi tidak langsung serta teknik literatur dan inkuiri.

\section{LITERATURDAN METODOLOGI}

\section{Komunikasi}

Secara terminologi, para ahli komunikasi memberikan pengertian komunikasi menurut sudut pandang dan pendapat mereka masing-masing diantaranya: Dani Vardiasnyah mengungkapkan beberapa definisi komunikasi secara istilah yang dikemukakan para ahli, seperti Jenis \& Kelly yang menyebutkan bahwa "komunikasi adalah suatu proses melaluimana seseorang (komunikator) menyampaikan stimulus (biasanya dalam bentuk kata-kata) dengan tujuan mengubah atau membentuk perilaku orang lainnya (khalayak)". Definisi ini pun mendapatkan dukungan teoritis dari Berelson \& Stainer yang menyatakan bahwa "komunikasi adalah suatu proses penyampaian informasi, gagasan, emosi, keahlian, dan lainlain. Melalui penggunaan simbol-simbol seperti kata-kata, gambar-gambar, angka-angka, dan lainlain". Lebih lanjut, Gode memberikan penegasan bahwa "Komunikasi adalah suatu proses yang membuat sesuatu dari yang semula yang dimiliki oleh seseorang (monopoli seseorang) menjadi dimiliki dua orang atau lebih". Brandlun secara implementatif memberikan masukan bahwa "komunikasi timbul didorong oleh kebutuhankebutuhan untuk mengurangi rasa ketidakpastian, bertindak secara efektif, mempertahankan atau memperkuat ego". Penjelasan lain mengenai proses komunikasi juga disampaikan oleh Reusch yang menyatakan bahwa "komunikasi adalah suatu proses yang menghubungkan satu bagian dengan bagian lainnya dalam kehidupan". Penjelasan terakhir terkait dengan komunikasi datang dari Weaver yang berpendapat bahwa "komunikasi adalah seluruh prosedur melalui mana pikiran seseorang dapat mempengaruhi pikiran orang lainnya" (Vardiansyah, 2008: 25-26).

Berbagai definisi di atas menggambarkan beberapa kesamaan sekaligus perbedaan di antara para teorisi dalam mendefinisikan komunikasi. Kesamaan atau kesepakatan mereka, setidaknya nampak dalam memahami komunikasi sebagai suatu proses, transaksional, dan simbolik.

Sebagai suatu proses, komunikasi bersifat kontinu, berkesinambungan, dan tidak memiliki akhir. Komunikasi juga dinamis, kompleks, dan senantiasa berubah. Komunikasi juga merupakan 
aktivitas transaksional. Dalam aktivitas komunikasi, di antara partisipan komunikasi sejatinya membangun makna dari pesan secara kooperatif. Dengan kata lain, dalam komunikasi, partisipan komunikasi selalu menegosiasikan makna. Dalam negosiasi ini, latar belakang masingmasing partisipan akan sangat berpengaruh dalam membangun kesamaan.

Sementara itu, sebagai aktivitas simbolik, komunikasi dapat diidentifikasi melalui penggunaan simbol-simbol dalam pesan-pesan yang digunakan. Simbol bisa diartikan sebagai representasi konseptual yang arbiter. Hal ini terjadi terutama dalam komunikasi yang menggunakan pesan-pesan verbal, misalnya dalam penggunaan bahasa. Manusia selalu memiliki kesepakatan dalam penggunaan kosakata tertentu, yang biasanya bersifat lokal dan unik. Kemampuan menggunakan simbol merupakan ciri eksklusif manusia, karenanya manusia sering juga disebut sebagai 'animal simbolikum' (makhluk yang selalu menggunakan simbol) (Santoso \& Setiansah, 2010: 5).

\section{Politik}

Ada beberapa buku yang memberikan pernyataan tentang apa itu politik. Salah satunya adalah buku Pengantar Ilmu Politik yang ditulis oleh Suryanto. Menurutnya, politik adalah bermacammacam kegiatan dalam suatu sistem politik (atau negara) yang berkaitan dengan proses menentukan tujuan-tujuan dari sistem itu dan melaksanakan tujuan-tujuan itu. Untuk melaksanakan tujuantujuan diperlukan kebijakan-kebijakan umum (public policies) yang menyangkut pengaturan dan pembagian (distribution) atau alokasi (allocation) dari sumber-sumber (resources) yang ada. Lebih lanjut ia menjelaskan bahwa untuk bisa berperan aktif dalam melaksanakan kebijakan-kebijakan tersebut, perlu dimiliki kekuasaan (power) beserta dengan kewenangan (authority) yang akan digunakan, baik untuk membina kerja sama maupun untuk menyelesaikan konflik yang mungkin timbul dalam proses itu. Cara-cara yang digunakan dapat bersifat meyakinkan (persuassive) atau bisa bersifat memaksa (coercism), karena tanpa adanya unsur paksaan, kebijakan hanya berupa perumusan keinginan (formulation of interest) (Suryanto, 2018:2).

\section{Intelektual}

Intelektual, berdasarkan pada Kamus Besar Bahasa Indonesia, sangat erat kaitannya dengan sifat intelek. Intelek didefinisikan sebagai istilah psikologi tentang daya atau proses pikiran yang lebih tinggi yang berkenaan dengan pengetahuan, daya akal budi, dan kecerdasan berpikir. Sedangkan kata intelektual memiliki pengertian sebagai sifat yang cerdas, berakal, dan berpikiran jernih yang berdasarkan pada ilmu pengetahuan. Kata intelek dan intelektual itu sendiri, secara konotatif, seringkali diidentifikasi pada kaum terpelajar atau cendekiawan (Sugiantoro, 2011)

\section{Komunikasi Intelektual}

Seperti yang telah dijelaskan pada pembahasan sebelumnya, intelektual identik dengan sifat cerdas, berakal, dan berpikiran jernih yang berdasarkan pada ilmu pengetahuan sehingga pengertian tersebut seringkali melekat pada orangorang yang terpelajar dan berwawasan luas. Di dalam ilmu komunikasi itu sendiri, intelektual merupakan salah satu aspek struktural yang ada pada komunikasi manusia. Secara spesifik, komunikasi intelektual tidak hanya sekedar untuk mengirim dan menerima pesan saja, tetapi juga untuk memahami makna yang ada di dalam pesan tersebut.

Mengutip pernyataan Zarefsky (1993: 2-3), Powers menjelaskan bahwa inti dari komunikasi adalah hubungan antara pesan dan orang-orang (the relationship between messages and people). Mengacu pada fokus ini, ada serangkaian kriteria yang harus dipenuhi, yaitu menspesifikasikan apa konsep intinya, menjelaskan bagaimana konsep inti ini membentuk ilmu tersebut, menyertakan sebanyak mungkin tentang aspekaspek ketertarikan disiplin ilmu saat ini, baik itu ilmiah secara retoris maupun sosial, baik secara retoris maupun sosial, serta mengungkapkan bagaimana bagian-bagian tersebut berhubungan 
secara sistematis antara satu dengan yang lainnya sehingga menunjukkan koherensi yang mendasari keragaman tersebut (1995: 191-192). Secara implementatif, penjelasan ini memiliki makna bahwa suatu bentuk komunikasi bisa disebut sebagai komunikasi intelektual jika memiliki konsep inti yang dapat dijelaskan dan mampu membentuk ilmu komunikasi yang bersumber dari banyak aspek, baik itu secara retoris maupun sosial, sehingga mampu menjelaskan kepaduan makna yang menjadi dasar atas keragaman intelektualisme yang ada di dalam komunikasi tersebut.

\section{Komunikasi Politik}

Mengutip pernyataan Dahlan (1999), komunikasi politik dapat diartikan sebagai suatu bidang atau disiplin yang menelaah perilaku dan kegiatan komunikasi yang bersifat politik, mempunyai akibat politik, atau berpengaruh terhadap perilaku politik. Sedangkan Meadow dalam Nimmo (2004) memiliki rujukan bahwa komunikasi politik merupakan bentuk pertukaran dari simbol dan pesan yang secara signifikan dibentuk atau memiliki konsekuensi-konsekuensi terhadap sistem politik (political communication refers to any exchange of symbol and message that to a significant which have been shaped by or have consequences for political system)(Cangara, 2016:29).

Sedangkan dalam sumber yang berbeda, Mc Nair mengutip Denton and Woordward yang memberikan defnisi komunikasi politik sebagai berikut: Diskusi tentang alokasi public resources (revenue), offcial authority (mereka yang diberikan kekuasaan untuk membuat peraturan, keputusan legislatif dan eksekutif), dan offcial sanction (penghargaan atau hukuman oleh Negara).Menurut Mc Nair, defnisi Denton and Woodward di atas termasuk di dalamnya retorika politik verbal dan tulisan, namun tidak termasuk komunikasi simbolik. Sedangkan menurut catatan Mc Nair, Doris Graber berpandangan bahwa komunikasi politik termasuk di dalamnya adalah paralinguistik seperti bahasa tubuh dan tindakan politik seperti boikot dan protes. Mc Nair sependapat dengan padangan Graber, bahkan pakaian apa yang digunakan, gaya rambut, tata rias, logo, dan semua elemen komunikasi yang ditujukan untuk membentuk citra politik termasuk dalam komunikasi politik. Dengan bersandar pada defnisi dari Denton and Woordward, Mc Nair menekankan komunikasi politik pada adanya intensi/maksud. Mc Nair juga memberikan pendapat bahwa ada tiga elemen dalam komunikasi politik, yaitu: organisasi politik, media, dan warga negara (2003: 4-6) (Damayanti \& Hamzah, 2017: 281).

\section{Komunikasi Intelektual sebagai Dasar dari Komunikasi Politik}

Tidak dapat dipungkiri bahwa inteletualisme merupakan modal utama dalam memecahkan setiap permasalahan yang ada di lingkungan sekitarnya, terlepas dari bidang atau topik bahasan apa yang sedang dibicarakan dan bagaimana mereka mengupas permasalahan tersebut secara kreatif dan sistematis. Wardaningtias menyebutkan bahwa kaum intelektual merupakan orang-orang berilmu yang tidak pernah puas atas segala usaha yang mereka lakukan. Mereka selalu berproses untuk menjadi lebih baik dari hari ke hari dengan selalu mempresentasikan apa yang ada di pikirannya secara cerdas serta mampu merealisasikan pemikirannya ke dalam lingkungan sekitarnya sehingga mereka cenderung mampu untuk terjun di mana saja dan kapan saja. Maka tak heran jika mereka selalu disebut-sebut sebagai agent of change (Wardaningtias, 2018).

Di dalam komunikasi politik, berkomunikasi secara intelek juga diperlukan, bahkan menjadi sebuah keharusan. Hal tersebut dinyatakan demikian karena pada penerapannya ketika berpolitik, orang dengan tingkat intelektual yang rendah cenderung tidak mampu untuk bersikap adil dalam menegakkan hukum, juga tidak mampu menyelesaikan kasus-kasus politik yang ada karena lebih mengutamakan kepentingan politiknya. Terlebih lagi, pada politik Indonesia yang semakin hari semakin gaduh karena berorientasi pada like or dislike (suka tidak suka) ketimbang pertimbangan yang rasional, imparsial, dan objektif menyebabkan kecenderungan para politisi yang berintelektual minus untuk bersikap anti-intelektual, insinuasi, 
argentum ad-hominem, hingga melakukan tindakan gulity by asssociation (mendakwa kesalahan seseorang dengan mengkaitkan masalah pribadi) (Mustaqim, 2019).

\section{Warganet (Netizen/Net Citizen)}

Mengacu pada pernyataan Michael Hauben yang dikutip oleh Katsuaki Suzuki, kata netizen secara etimologis berasal dari dua kata, yaitu kata network yang berarti jaringan dan citizen yang berarti masyarakat. Secara harfiah, warganet (netizen) adalah masyakarat yang tercipta dari jaringan digital, atau masyarakat jaringan (net-citizens). Hal itu kemudian diartikan sebagai sekumpulan orangorang yang menggunakan jaringan digital, seperti Internet, untuk berkomunikasi dengan orang lain, untuk mencari informasi, atau untuk menunjukkan ide-ide mereka melalui jaringan (2007:1).

\section{Komunikasi Intelektual sebagai Bentuk Partisipasi Politik Warganet}

Terlepas apakah seseorang memiliki posisi khusus di dalam lingkungan kesehariannya atau tidak, berkomunikasi secara intelek tetap harus diutamakan. Inilah yang kemudian menjadi tantangan tersendiri bagi masyarakat, khususnya para warganet yang saat ini menghadapi kondisi dan situasi politik yang tidak menentu. Dalam menyikapi kondisi politik yang tidak menentu seperti ini, warganet sebagai pihak yang dianggap memiliki pemikiran baru senantiasa dituntut untuk lebih cepat menyesuaikan diri dalam memecahkan permasalahan politik serta berkemampuan untuk menghasilkan kemampuan baru dari permasalahan yang telah mereka pecahkan sebelumnya. Selain itu, dalam berkomunikasi secara politis, mereka juga diharapkan mampu memberikan kontribusikontribusinya dengan memberikan terobosanterobosan politik yang benar-benar baru, memiliki ide cemerlang, serta memiliki tanggung jawab untuk menentang suatu perbuatan yang salah dengan menunjukkan yang hakiki. Tidak hanya itu, sebagai bagian masyarakat dengan tingkat intelektual yang tinggi, warganet seharusnya juga mampu menjawab berbagai permasalahan bangsa yang hadir di tengah-tengah kehidupan berbangsa dan bernegara, khususnya pada bidang politik Indonesia seperti Pemilu 2019 dan Debat Pilpres 2019.

\section{Jejaring Sosial (Social Networking)}

Dikutip dari jurnal IPTEK-KOM, Juditha (2011) Situs jejaring sosial yang dalam bahasa Inggris disebut social network sites merupakan sebuah web berbasis pelayanan yang memungkinkan penggunanya untuk membuat profil, melihat daftar pengguna yang tersedia, serta mengundang atau menerima teman untuk bergabung dalam situs tersebut. Tampilan dari situs jejaring sosial ini menampilkan halaman profil pengguna, yang di dalamnya terdiri dari identitas diri dan foto pengguna.

Secara rinci, jejaring sosial merupakan bentuk dari media sosial dan juga merupakan jenis media massa yaitu berupa media digital. Media massa sebagai saluran informasi bagi khalayak luas selalu hadir dengan beragam pemberitaan. Khalayak tidak dapat menghindari akan kebutuhannya terhadap informasi, baik dari dunia politik, ekonomi, pendidikan, sosial, budaya, teknologi, dan lainnya. Media sosial yang dalam bahasa Inggris "Social Media" menurut tata bahasa terdiri dari kata "social" yang memiliki arti kemasyarakatan atau sebuah interaksi, dan "media" adalah sebuah wadah atau tempat sosial itu sendiri. Media sosial adalah sebuah media online dengan para penggunanya bisa dengan mudah berpartisipasi, berbagi dan menciptakan isi meliputi blog, jejaring sosial, wiki, forum, dan dunia virtual. Blog, jejaring sosial dan wiki merupakan bentuk media sosial yang paling umum digunakan oleh masyarakat di seluruh dunia (Juditha, 2011).

\section{Media Sosial}

Mengacu pada penjelasan Mandibergh yang dikutip oleh Nasrullah, media sosial dapat didefinisikan sebagai "media yang mewadahi kerja sama di antara pengguna yang menghasilkan konten (User generated content)" (2015).

Melaluijurnalnya, Davidmenuturkan ahwa suatu 
media dapat dikategorikan sebagai media sosial jika pada penerapannya pesan yang disampaikan tidak hanya untuk satu orang saja namun bisa ke berbagai banyak orang contohnya pesan melalui SMS ataupun internet. Selain itu, pesan yang disampaikan haruslah bersifat bebas, tanpa harus melalui suatu Gatekeeper. Dalam penerimaannya, estimasi waktu pesan yang disampaikan cenderung lebih cepat di banding media lainnya, sedangkan pada tindakan arus balik terhadap pesan yang disampaikan, penerima pesanlah yang berlaku sebagai penentu waktu untuk berinteraksi (2017).

\section{Teori Semiotika}

Menurut Littlejohn yang dikutip oleh Morissan dalam bukunya yang berjudul Teori Komunikasi Massa, semiotika mencakup mengenai bagaimana tanda mewakili objek, ide, situasi, keadaan, perasaan, dan sebagainya yang berada di luar diri. Sedangkan konsep dasar yang menyatukan tradisi semiotika adalah 'tanda' yang diartikan sebagai sebuah stimulus yang mengacu pada sesuatu yang bukan dirinya sendiri (1999:61). Tanda itu sendiri, menurut John Powers(1995), merupakan dasar dari semua komunikasi. Dijelaskan seperti itu karena tanda menunjuk atau mengacu pada sesuatu yang bukan dirinya sendiri, sedangkan makna atau arti adalah hubungan antara objek atau ide dengan tanda. Kedua konsep tersebut menyatu dalam berbagai teori komunikasi, khususnya teori komunikasi yang memberi perhatian pada simbol, bahasa, serta tingkah laku nonverbal. Kelompok teori ini menjelaskan tentang bagaimana tanda dihubungkan dengan makna dan bagaimana tanda-tanda tersebut diorganisir. Lebih lanjut dia menegaskan bahwa tanda mutlak diperlukan dalam menyusun pesan yang hendak disampaikan. Tanpa tanda, maka pesan yang disampaikan dapat membingungkan penerima (Morissan, Wardani, \& Hamid, 2013:173).

Sedangkan semiotik menurut Charles Sanders Peirce yang dikutip dalam Littlejohn (Theories of Human Communiication, 1996:64) adalah suatu hubungan di antara tanda, objek, dan makna. Berdasarkan pada pengertian tersebut, bila kita berbicara mengenai semiotika, kita akan berhubungan dengan suatu tanda. Umberto Eco juga menjelaskan bahwa tanda dapat dipergunakan untuk menyatakan kebenaran, sekaligus juga kebohongan(Sobur, 2009, hal. 18).

\section{Teori Interaksionisme Simbolik}

Teori interaksionisme simbolik merupakan sebuah teori yang terbentuk dari pemikiran George Herbert Mead. Pada dasarnya, teori ini menekankan pada hubungan antara simbol dengan interaksi, serta inti dari pandangan pendekatan ini adalah individu.Menurut West-Turner (2008: 96) dalam Siregar (2011:103), interaksi simbolik pada intinya menjelaskan tentang kerangka referensi untuk memahami bagaimana manusia, bersama dengan orang lain, menciptakan dunia simbolik dan bagaimana cara dunia membentuk perilaku manusia.

Interaksi simbolik ada karena ide-ide dasar dalam membentuk makna yang berasal dari pikiran manusia (Mind) mengenai diri (Self), dan hubungannya di tengah interaksi sosial, dan bertujuan akhir untuk memediasi, serta menginterpretasi makna di tengah masyarakat (Society) dimana individu tersebut menetap. Melalui teori ini, muncul tiga konsep pemikiran Mead yang menjadi dasar dari teori ini. Tema pertama pada interaksi simbok berfokus pada pentingnya membentuk makna bagi perilaku manusia, dimana dalam teori interaksi simbolik tidak bisa dilepaskan dari proses komunikasi, karena awalnya makna itu tidak ada artinya, sampai pada akhirnya di konstruksi secara interpretatif oleh individu melalui proses interaksi, untuk menciptakan makna yang dapat disepakati secara bersama. Hal ini sesuai dengan tiga dari tujuh asumsi karya Herbert Blumer (1969) dalam WestTurner (2008:99), yaitu: (1) manusia bertindak terhadap manusia lainnya berdasarkan makna yang diberikan orang lain kepada mereka, (2) makna diciptakan dalam interaksi antar manusia, dan (3) makna dimodifikasi melalui proses interpretif.

Tema kedua pada interaksi simbolik berfokus pada pentingnya "Konsep diri" atau "SelfConcept", di mana pada tema interaksi simbolik ini menekankan pada pengembangan konsep diri 
melalui individu tersebut secara aktif, didasarkan pada interaksi sosial dengan orang lainnya. Tema ini memiliki dua asumsi tambahan, yaitu (1) individu-individu mengembangkan konsep diri melalui interaksi dengan orang lain, dan (2) konsep diri membentuk motif yang penting untuk perilaku (West \& Turner, 2008:101).

Tema terakhir pada interaksi simbolik berkaitan dengan hubungan antara kebebasan individu dan masyarakat, dimana asumsi ini mengakui bahwa norma-norma sosial membatasi perilaku tiap individunya, tapi pada akhirnya tiap individu-lah yang menentukan pilihan yang ada dalam sosial kemasyarakatannya. Fokus dari tema ini adalah untuk menjelaskan mengenai keteraturan dan perubahan dalam proses sosial. Asumsi-asumsi yang berkaitan dengan tema ini adalah: (1) orang dan kelompok masyarakat dipengaruhi oleh proses budaya dan sosial, dan (2) stuktur sosial dihasilkan melalui interaksi sosial (Siregar, 2011:103-105).

\section{Metodologi}

Penelitian ini menggunakan pendekatan kualitatif yang menggunakan eksploratif sebagai teknik analisis data. Penelitian eksploratif dipilih karena untuk meneliti secara holistik (menyeluruh) terkait dengan suatu kejadian. Informan dalam penelitian ini terbagi menjadi dua, yang pertama adalah yang berasal dari narasumber politik yang terlibat dalam Debat Pilpres 2019, sedangkan Informan yang kedua datang dari pihak warganet yang mengamati dan menganalisis makna percakapan para narasumber tersebut. Penelitian dilakukan melalui dua tahap, yaitu secara primer dengan menjadi pengamat tidak langsung (nonparticipant observer) dan melalui tahapan sekunder yaitu dengan teknik literatur dan inkuiri. Fokus dalam penelitian ini adalah hasil pembahasan warganet, baik itu berupa pengamatan, kajian, dan pernyataan, terkait dengan bentuk komunikasi yang dikemukakan oleh narasumber politik ketika membahas perkembangan hasil Pemilu 2019.

\section{TEMUAN DAN DISKUSI}

Berdasarkan dari data-data yang sebelumnya telah dikumpulkan melalui wawancara dan studi dokumen, maka peneliti menemukan berbagai temuan yang digunakan sebagai bahan analisis pada penelitian terkait dengan partisipasi warganet dalam mengidentifikasi komunikasi intelektual narasumber politik terkait perkembangan hasil Pemilu 2019.

Seperti yang telah kita ketahui dan kita lihat, rakyat Indonesia baru saja turut berpartisipasi dalam pesta demokrasi rakyat yang diadakan setiap lima tahun sekali. Dalam acara akbar tersebut, tidak ada obrolan lain selain tentang siapa yang dianggap berhak dan mampu menduduki kursi nomor satu di pemerintahan Indonesia selama lima tahun kedepan. Acara ini biasa kita ketahui dengan nama Pemilu 2019 yang mungkin saat ini lebih familiar dengan istilah Pilpres 2019.

Jauh sebelum acara ini digelar, sudah banyak bentuk pemberitaan yang membahas tentang “perjalanan politik" menuju Pilpres 2019, mulai dari profil kandidat bakal calon, pembentukan kubu yang berisikan sederet partai politik golongan mayoritas, pemilihan tim sukses dari masing-masing kubu, hingga pada spekulasi pro dan kontra tentang kualitas pasangan calon yang dikeluarkan oleh tim sukses masing-masing kubu. Perjalanan politi kini pun juga menyiarkan sebuaha cara kompetisi, dimana acara tersebut dikhususkan untuk pasangan calon yang dibagi menjadi lima putaran dan bertujuan untuk mengadu visi dan misi, gagasan serta program kerja. Kompetisi ini kita kenal dengan sebutan Debat Pilpres 2019.

Kehadiran Debat Pilpres sebagai bagian dari proses Pemilu sebenarnya bukanlah sebuah hal yang baru karena sebelumnya pernah diadakan pada Pemilu periode 2014 lalu. Namun, yang menjadikan Debat Pilpres pada periode 2019 ini lebih ramai ketimbang periode 2014 karena beberapa faktor, seperti: (1) pertandingan ulang (rematch) antara Prabowo dengan Jokowi; (2) Kehadiran Sandiaga Uno yang digadang-gadang mampu mengimbangi kekuatan politik Joko Widodo karena gagasannya yang dianggap mewakili golongan kaum minoritas dan masyarakat generasi millenial; dan (3) munculnya isu politik yang menjelaskan bahwa pertandingan politik antara Jokowi dengan 
Prabowo merupakan kelanjutan pertandingan lama antara Megawati dengan SBY yang dikemas dengan gaya baru. Namun, apaun faktor politiknya, Debat Pilpres pada periode 2019 ini menjadi salah satu cara pemerintah dalam menilai kualitas dari masing-masing pasangan calon.

Dalam dunia yang menuntut perilaku yang dinamis dan pemikiran yang kritis, ada beberapa pertimbangan yang dapat dijadikan sebagai indikator tingkat intelektualitas manusia. Salah satunya adalah bagaimana dia berkomunikasi sesuai dengan ilmu yang dimiliki. Tanpa kita sadari, kita selalu menakar intelektualitas seseorang dari bagaimana orang lain berbicara tentang suatu kejadian atau fenomena yang ada baik yang ada di sekitar kita, di sekitar orang yang berbicara, atau bahkan keduanya.

Secara kasat mata, tingkat intelektualitas seorang pakar politik secara umum ditentukan setidaknya dari tiga hal, yaitu: (1) bagaimana dia berpenampilan di hadapan media; (2) diksi yang digunakan ketika berdiplomasi berdasarkan pemikiran kritisnya, dan; (3) latar belakang pengalaman yang dimiliki. Hal ini sekilas terdengar kontradiktif, mengingat faktor pengalaman yang merupakan indikator utama seseorang dalam menilai intelektualitas seseorang justru harus disebutkan terakhir. Ini diakibatkan karena hal tersebut masih bersifat samar, di mana tidak banyak orang mengetahui latar belakang pengalaman yang dimiliki secara massal. Masyarakat cenderung menebak tingkat intelektualitasnya dari apa yang dikenakan ketika menghadiri suatu acara berita, sehingga tak jarang orang-orang cenderung mendapatkan hasil yang sebaliknya ketika dia berkomunikasi.Tidak sedikit contoh di mana pakar politik tertentu berpenampilan rapi yang berkomunikasi layaknya penyaring yang tidak memiliki saringan dan demikian juga sebaliknya, tidak sedikit juga pakar yang berpenampilan ala kadarnya yang berkomunikasi sejajar dengan para petinggi negara kita. Dan pada akhirnya, secara perlahan masyarakat baru mengetahui tingkat intelektualitasnya melalui dua tahapan, di mana (1) dia melakukan 'sepak terjang' di sebuah kejadian atau kasus, dan (2) ketika media menyiarkan latar belakang, pengalaman, dan pencapaian karirnya secara keseluruhan ke hadapan publik.

Terlepas dari pengamatan sekilas terkait dengan bagaimana seseorang menilai tingkat intelektualnya, Keyes mengemukakan bahwa ada 12 indikator yang mendasari tingkat intelektualitas seseorang, yang pertama adalah bersikap gigih (persistence) ketika solusi atas suatu masalah tidak benar-benar terlihat. Kedua adalah mengurangi sikap impulsif (decreasing impulsivity) dengan cara menghindari tindakan yang tidak didasari oleh pemikiran, mengevaluasi situasi secara hati-hati, mencari saran dari sumber lain, mempetimbangkan konsekuensi atas tindakan, serta memastikan bahwa kita telah memahami arahan-arahan sebelum bertindak. Indikator selanjutnya adalah mendengarkan dengan memahami dan rasa empati (listening with understanding and empathy) sehingga kita menjadi sensitif dengan perasaan, kemampuan, dan pemikiran orang lain.

Selanjutnya adalah bersikap fleksibel ketika berpikir (flexible in thinking) dengan cara mencoba untuk menemukan ide yang berbeda dan mengevaluasi apakah ide-ide tersebut masuk akal, serta mengganti pendekatan apablia apa yang kita lakukan tidak membuahkan hasil. Metakognisi (metacognition) menjadi indikator penentu intelektual selanjutnya, di mana ini bisa diperoleh ketika seseorang memiliki kesadaran terhadap pemikirannya sendiri serta mampu mendeskripsikan langkah-langkah pemecahan masalah atau dengan melakukan tugas mental lainnya. Indikator keenam adalah selalu memeriksa akurasi dan presisi (checkin on accuracy and precision)dengan memperhatikan hingga rincian terkecil, memeriksa setiap sumber yang ada untuk memastikan bahwa upaya tersebut akurat, dan mengkoreksi kesalahan. Kita juga dituntut unuk selalu mengajukan pertanyaan dan permasalahan (questioning and problem posin) untuk meningkatkan tingkat intelektual dengan bertanya semua jenis pertanyaan yang berhubungan dengan masalah, tidak takut untuk mengakui bahwa kita tidak tahu, serta waspada terhadap perbedaan dan meminta klarifikasi. Seseorang juga dapat dikatakan telah memiliki intelektual yang tinggi 
jika dia mampu menggambarkan pengalaman lamanya yang kemudian diaplikasikan ke dalam situasi yang baru (drawing on past experience and applying it to the new situation).

Selain itu, intelektual seseorang bisa diukur tinggi atau tidak jika dia memiliki presisi terhadap kata-kata dan pemikirannya (precision on language and thought), di mana hal tersebut dapat kita ketahui dari ekspresi oral dan tertulisnya yang singkat, deskriptif, dan koheren, mampu berbicara dalam ilmu yang utuh, menyediakan bukti pendukung di tiap idenya, serta mampu mengelaborasi, mengklarifikasi, dan menjelaskan pemikirannya secara terminologis. Orang berintelektual juga bisa kita temui ketika dia mampu menggunakan semua pemahamannya dalam memecahkan masalah (uses all of the senses) yang disertai dengan rasa ingin tahu yang besar (curiosity). Indikator intelektual yang terakhir yang paling sering kita ketahui adalah ketika seseorang memiliki sifat cerdik, orisinalitas, berwawasan, dan kreativitas (ingenuity, originality, insightful, creativity) dalam merumuskan solusi masalah (Keyes, 2013).

Lalu, terkait dengan diksinya, hal tersebut menjadi faktor penentu penilaian masyarakat terhadap intelektualitas yang dimiliki narasumber politik, khususnya ketika membahas acara politik besar seperti Pemilu 2019. Ada yang menilai bahwa seberapa banyak atau kompleks diksinya menentukan seberapa besar ilmu yang dia miliki. Ini berarti cara berkomunikasi seorang narasumber menjadi label harga yang utama. Semakin banyak dan rumit kosa kata yang dapat dipahami dan diimplementasikan ke dalam suatu bahasan, secara tidak langsung orang-orang akan beranggapan bahwa dia adalah seorang narasumber yang intelek, terlepas apakah masyarakat juga memahami dengan benar maknanya atau tidak.

Sejalan dengan perkembangan zaman, teknologi komunikasi pun juga berinovasi sesuai dengan tuntutan zaman. Sebagai makhluk yang turut menjadi saksi dalam setiap fenomena perkembangan kedua elemen besar tersebut, tentunya kita mencoba, membandingkan, dan menikmati beragam teknologi yang ada di setiap zamannya. Di antara sekian banyak bentuk, hasil teknologi yang sampai saat ini kita gandrungi adalah media sosial dan jejaring sosial. Seperti yang kita tahu, media sosial dan jejaring sosial merupakan media baru yang selalu mengikuti apa yang saat ini sedang menjadi tren atau populer di kalangan masyarakat. Kedua media tersebut juga menjadi sarana komunikasi kita yang utama, baik itu ketika sedang berinteraksi dengan orang-orang yang ada dalam ruang lingkup digital kita, maupun ketika kita sedang berselancar mengarungi arus utama informasi.

Di era berpikir kritis seperti sekarang, media sosial pun juga secara tidak langsung menambahkan fungsinya. Fungsi tersebut adalah menjadi mediator multi arah, baik itu horizontal (antara warganet dengan para pejabat negara) atau vertikal (sesama masyarakat awam). Secara umum, media sosial mampu menjembatani komunikasi yang dibangun antara satu orang dengan orang yang lainnya berdasarkan pemikiran yang menjadi hasil dari pengamatan suatu kejadian tertentu. Sedangkan secara rinci, media sosial mampu menyediakan ruang virtual di mana orangorang yang berpartisipasi dalam suatu aktivitas atau kejadian yang sama secara virtual juga dapat menyalurkan apa yang menjadi dasar dari pemikiran kritisnya.

Dalam mengamati setiap bentuk komunikasi yang dikemukakan oleh narasumber politik, khususnya ketika membahas hasil perkembangan Pemilu 2019, partisipasi warga sangat diperlukan. Hal ini dapat menjadi pemicu sosial bagi masyarakat lainnya untuk ikut berpikir tidak hanya secara demokratis, tapi juga secara kritis. Oleh karena itu, masyarakat saat ini pun juga harus berperan aktif untuk selalu mengikuti obrolan apa saja yang dibahas dalam setiap segmen terkait dengan pembahasan soal perkembangan Pemilu 2019. Salah satu cara yang dapat ditempuh agar bisa menjadi aktif dalam berpartisipasi adalah dengan menjadi masyarakat di jaringan digital. Hal ini perlu ditempuh karena derasnya informasi yang masuk mengharuskan kita tidak hanya untuk sekedar melihat, namun juga membandingkan antara satu narasumber dengan narasumber lainnya, serta turut memberikan tanggapan dan respon tentang 
apa dan bagaimana yang seharusnya dilakukan oleh narasumber politik dalam mengomentari setiap perkembangan yang tampak terkait dengan Pemilu 2019. Selain itu, keterlibatan warga secara digital juga dapat menjadi cerminan revisi politik Indonesia yang demokratis, kritis, dan independen.

\section{SIMPULAN}

Berdasarkan hasil penelitian dan pembahasan maka dapat disimpulkan bahwa komunikasi intelektual mampu dijadikan sebagai dasar dari narasumber politik untuk berkomunikasi secara politik mengenai perkembangan hasil Pemilu 2019. Selain itu, komunikasi intelektual juga dapat menjadi pemicu utama bagi warganet untuk mengamati dan menganalisis setiap percakapan dan perdebatan politik yang diutarakan oleh masing-masing narasumber politik secara kritis sehingga mampu memberikan pemikiran dan terobosan-terobosan untuk menghindari sikap anti-intelektual serta menciptakan sistem politik yang berprinsip pada rasionalitas, imparsial, dan objektivitas.

\section{DAFTAR PUSTAKA}

APJII. (2018, March 22). Cerita diBalik Kesuksesan Pemerintah Tarif Pajak Google. Pengguna Gen Millenial Lebih Suka Snapchat dan Instagram Ketimbang Facebook, hal. 6.

Blumer, H. (1969). Symbolic Interactionism: Perspective and Method. London: University of California Press.

Cangara, H. (2016). Komunikasi Politik : Konsep, Teori, dan Strategi. Jakarta: Raja Grafindo Persada.

Damayanti, N., \& Hamzah, R. E. (2017). Strategi Kampanye Politik Pasangan Jokowi-JK pada Pemilihan Presiden 2014. Wacana, 279-290.

David, E. M. (2017). Pengaruh Konten Vlog dalam Youtube terhadap Pembentukan Sikap Mahasiswa Ilmu Komunikasi Fakultas Ilmu Sosial dan Politik Universitas Sam Ratulangi. Acta Diurna.
Fachrudin, A. (2019, January 02). Media Massa dan Pemilu 2019. Dipetik Julu 31, 2019, dari akurat.co: https://akurat.co/news/ id-461469-read-media-massa-danpemilu-2019

Handy. (2019, July 15). Identifikasi Responden terhadap Perbandingan antara Debat Pilpres 2014 dengan Debat Pilpres 2019. (D. Soelistyowati, Pewawancara)

Handy. (2019, Juli 15). Intensitas dan Pemahaman Responden terhadap Kondisi Politik di Indonesia. (D. Soelistyowati, Pewawancara)

Handy. (2019, July 15). Prediksi Responden terhadap Hasil Akhir Debat Pilpres 2019. (D. Soelistyowati, Pewawancara)

Ibnu. (2019, July 17). Analisis Kecakapan Komunikasi Pasangan Calon dalam Debat Pilpres 2019. (D. Soelistyowati, Pewawancara)

Juditha, C. (2011, Juni). Hubungan Penggunaan Situs jejaring Sosial Facebook terhadap Perilaku Remaja di Kota Makassar. IPTEKKOM, XIII(1).

Keyes, J. (2013, December 5). 12 Intellectual Indicators. Dipetik November 21, 2019, dari Prezi: https://prezi.com $/ \mathrm{m} /$ edw5bj2pfjc1/12-intellectual-indicators/

Klapper, J. T. (1963). Mass Communication Research : An Old Road Resurveyed. Public Opinion Quarterly, 515-527.

Littlejohn, S. W. (1996). Theories of Human Communiication (5th ed.). New York: Wadworth.

Littlejohn, S. W. (1999). Theories of Human Communication (6th ed.). Albuquerque: Wadworth Publishing.

Littlejohn, S. W. (2005). Theories of Human Communication (8th ed.). Albuquerque: Wadworth Publishing.

Maulana, A. A. (2019, July 14). Analisis Kemampuan Komunikasi Pasangan Calon dalam Debat Pilpres 2019. (D. Soelistyowati, Pewawancara) 
Maulana, A. A. (2019, July 14). Analisis Responden terhadap Netralitas Stasiun Televisi Terkait Pemberitaan Seputar Debat Pilpres 2019. (D. Soelistyowati, Pewawancara)

Maulana, A. A. (2019, July 14). Identifikasi Responden terhadap Perbandingan antara Debat Pilpres 2014 dengan Debat Pilpres 2019. (D. Soelistyowati, Pewawancara)

McNair, B. (2003). An Introduction to Political Communication. New York: Routledge.

Morissan, Wardani, A. C., \& Hamid, F. (2013). Teori Komunikasi Massa. Bogor: Ghalia.

Mulyadi. (2019, July 15). Analisis Kecakapan Komunikasi Pasangan Calon dalam Debat Pilpres 2019. (D. Soelistyowati, Pewawancara)

Mulyadi. (2019, July 14). Intensitas dan Pemahaman Responden terhadap Perkembangan Kondisi Politik di Indonesia. (D. Soelistyowati, Pewawancara)

Mustaqim, M. F. (2019, October 19). Opini Pilihan. Dipetik November 20, 2019, dari GeoTimes: http://geotimes.co.id/op-ed/ anti-intelektualisme-semakin-merebak-diruang-publik/

Nasrullah, R. (2015). Media Sosial: Perspektif Komunikasi, Budaya, dan Sosioteknologi. Bandung: Simbiosa Rekatama Media.

Powers, J. D. (1995). On the Intellectual Structure of the Human Communication Discipline. Communication Education, 191-222.

Powers, J. H. (1995). Communication Education 4 - On the Intellectual Structure of the Human Communication Discipline.

Rubin, A. M. (1994). Media Effects : A Uses and Gratifications Perspectives.

Santoso, E., \& Setiansah, M. (2010). Teori Komunikasi. Yogyakarta: Graha Ilmu.

Siregar, N. S. (2011, October). Kajian tentang Interaksionisme Simbolik. Perspektif, 4(2), 100-110.

Sobur, A. (2009). Semiotika Komunikasi. Bandung: Remaja Rosdakarya.
Sugiantoro, H. (2011, May 23). Intelek, Intelektual, Ulil Albab... Dipetik 11 20, 2019, dari Kompasiana: https://www.kompasiana. com/ahmadelpena/5500d0bda333113e095 109f3/intelek-intelektual-ulil-albab

Suryanto. (2018). Pengantar Ilmu Komunikasi Politik. Bandung: Pustaka Setia.

Susanto, I. (2019, July 17). Analisis Responden terhadap Netralitas Stasiun Televisi Terkait Pemberitaan Debat Pilpres 2019. (D. Soelistyowati, Pewawancara)

Susanto, I. (2019, July 17). Prediksi Responden terhadap Hasil Akhir Debat Pilpres 2019. (D. Soelistyowati, Pewawancara)

Suzuki, K. (2007). resume. Dipetik 08 10, 2019, dari gsis.kumamoto-u.ac.jp: www.gsis. kumamoto-u.ac.jp/ksuzuki/resume/ addresses/a30727.pdf

Vardiansyah, D. (2008). Filsafat Ilmu Komunikasi : Suatu Pengantar. Jakarta: Indeks.

Wardaningtias, A. T. (2018, February 3). Politik. Dipetik November 20, 2019, dari Kompasiana: http://www.kompasiana. com/baligh/5a75730bab12ae3ca0257af3/ kaum-intelektual-sebagai-sapu-bersihdalam-dunia-politik

West, R., \& Turner, L. H. (2008). Pengantar Teori Komunikasi: Analisis dan Aplikasi. Jakarta: Salemba Humanika.

Wiendijarti, I. (2008). Pengaruh Kredibilitas Narasumber Berita Politik terhadap Internalisasi Nilai Berita Politik. Jurnal Ilmu Komunikasi, 33-41.

Woolley, J. K., Limperos, A. M., \& Oliver, M. B. (2010). The 2008 Presidential Election, 2.0 : A Content Analysis of User-Generated Political Facebook Groups. Journal Mass Communication and Society, XIII.

Zarefsky, D. (1993). Presidential's Column: Does Intellectual Diversity Serve Us Well? Spectra, 2-3. 